\title{
"Jihād and the Religious Legitimacy of the Early Qajar State ", in : Robert Gleave, ed., Religious and Society in Qajar Iran. Londres et New York, Routdledge Curzon, 2005, pp. 41-70.
}

\section{Denis Hermann}

\section{OpenEdition}

\section{Journals}

Édition électronique

URL : http://journals.openedition.org/abstractairanica/17781

DOI : 10.4000/abstractairanica. 17781

ISSN : 1961-960X

Éditeur :

CNRS (UMR 7528 Mondes iraniens et indiens), Éditions de l'IFRI

Édition imprimée

Date de publication : 15 mai 2007

ISSN : 0240-8910

\section{Référence électronique}

Denis Hermann, « " Jihād and the Religious Legitimacy of the Early Qajar State », in : Robert Gleave, ed., Religious and Society in Qajar Iran. Londres et New York, Routdledge Curzon, 2005, pp. 41-70. », Abstracta Iranica [En ligne], Volume 28 | 2007, document 177, mis en ligne le 18 septembre 2007, consulté le 25 septembre 2020. URL : http://journals.openedition.org/abstractairanica/17781 ; DOI : https://doi.org/10.4000/abstractairanica.17781

Ce document a été généré automatiquement le 25 septembre 2020.

Tous droits réservés 


\title{
" Jihād and the Religious Legitimacy of the Early Qajar State ", in : Robert Gleave, ed., Religious and Society in Qajar Iran. Londres et New York, Routdledge Curzon, 2005, pp. 41-70.
}

\author{
Denis Hermann
}

Robert Gleave nous a déjà fourni de nombreuses contributions sur le droit shi'ite moderne, et notamment la question du jehād. Il analyse ici le regard porté par quatre juristes du début de la période qājār sur le jehād : 'Alī b. Moḥammad 'Alī al-Ṭabāṭabā'î (m. 1231/1816), Mīrzā Abū al-Qāsem b. Mohammad al-Qommī (m. 1231/1816), ŠeyH Ja'far Hુeḍr Kāšef al-Ġețā' (m. 1227/1812) et Mīrzā Moḥammad b. 'Abd al-Nabī al-AḤbārī al-Neyšābūrī (m. 1233/1818). Les trois premiers appartenaient à l'école oṣūlī. Le dernier d'entre eux, Neyšābūrī, fut le dernier grand représentant de l'école aHbārī à la période moderne. Leurs attitudes respectives vis-à-vis du jehād furent extrêmement ambiguës et complexes. L'A. analyse ici avec grande minutie les ouvrages de droit que rédigèrent ces quatre foqahā et plus précisément les passages consacrés à la question du jehād, et plus généralement de la guerre, au cours de l'occultation majeure (ǵeybat-e kobrā). Même si l'approche de chacun de ces juristes est légèrement différente, aucun d'entre eux n'accordaient réellement de légitimité au jehād au cours de l'occultation majeure. Ils préféraient, le plus souvent, parler de défense $($ defā $)$. Pourtant, dans les faits, ces derniers appuyèrent le souverain qājār Fatḥ-'Alī Šāh dans sa déclaration de jehād contre les Russes. Ils rédigèrent même des fatvā pour cela. Celles-ci contredisent ouvertement leurs conclusions présentées dans leurs traités de droit. La symbolique du jehād était tellement forte que le souverain ne pouvait se contenter d'appeler simplement à la guerre (jang). Les 'olamā décidèrent donc d'appuyer cet appel.

2 Comme le démontre l'A., la question du jehād permet toujours à un auteur shi'ite de s'exprimer concernant la légitimité du gouvernement au cours de l'occultation. Ainsi, 
l'un des principaux intérêts de cet article est de parvenir à démontrer que si ces juristes shi'ites accordèrent de fait une légitimité au souverain pour mener le jehād contre les Russes, le pouvoir qājār demeurait pour ces derniers illégitime (jāer). Leurs ouvrages de droit le démontrent largement. Ainsi, il ne s'agit pas uniquement d'un article minutieux sur le statut du jehād dans le feqh shi'ite. Les conclusions historiques que propose Robert Gleave sont extrêmement intéressantes pour l'histoire des relations entre 'olamā shi'ites et Etat au début de l'époque qājār. Jusqu'à présent, les chercheurs ont surtout travaillé sur des sources plus tardives.

INDEX

Thèmes : 4.2.1. Safavides et Qâjârs

\section{AUTEURS}

DENIS HERMANN

IFRI - Téhéran 